Реферат. В фондах библиотек научных учреждений России сохранились личные книжные собрания выдающихся ученых. Они являются ценными объектами культурно-исторических исследований, частично сохраняя свою информационную значимость. В статье рассказывается о коллекции известного ученого-химика, академика А.Е. Чичибабина, обнаруженной в фондах библиотеки Института органической химии им. Н.Д. Зелинского РАН. Коллекция была передана библиотеке после отъезда ученого из страны и обезличена в связи с лишением владельца ученых званий и гражданства СССР. По сохранившимся экземплярам с владельческими знаками и спискам переданных книг проведен начальный этап реконструкции коллекции. Все выявленные издания имеют личную подпись ученого либо следы ее присутствия ранее, ряд экземпляров содержит дарственные надписи, владельческие пометы, отметки книжных магазинов. Качественный анализ показал, что тематика изданий относится к различным областям химической науки, представлявшей непосредственный профессиональный интерес владельца. Собрание имеет достаточно широкий хронологический охват, разнообразно по типу изданий (монографии, периодика, справочники, труды университетов, словари, практикумы и др.), многоязычно. О высоком научном уровне говорит присутствие в нем работ многих выдающихся русских и зарубежных химиков, лауреатов Нобелевской премии начала XX века. Библиофильский характер коллекции придает наличие книг XVIII и начала XIX в., отражающих основные периоды развития науки. Дальнейшее изучение изданий из личной библиотеки академика А.Е. Чичибабина добавит новые штрихи к биографии ученого, истории формирования его научной школы и поможет проследить научные и личные связи с коллегами из России и других стран.

Ключевые слова: личная библиотека, научное наследие, история химии, А.Е. Чичибабин.

Для цитирования: Евдокиленкова Ю.Б., Соболева H.O. Материалы к реконструкции личной библиотеки академика А.Е. Чичибабина // Библиотековедение. 2018. Т. 67, № 3. С. 291-298. DOI: 10.25281/0869-608X-2018-67-3-291-298.

Б урное развитие науки и техники на рубеже XIX - XX вв. вызвало рост числа публикаций в периодических изданиях, монографий, патентов. Исследователи стремились следить за новыми достижениями в интересующих их областях науки, и эту задачу помогали решить библиотеки. В России в XIX в. помимо публичных уже существовали и специальные научные библио-

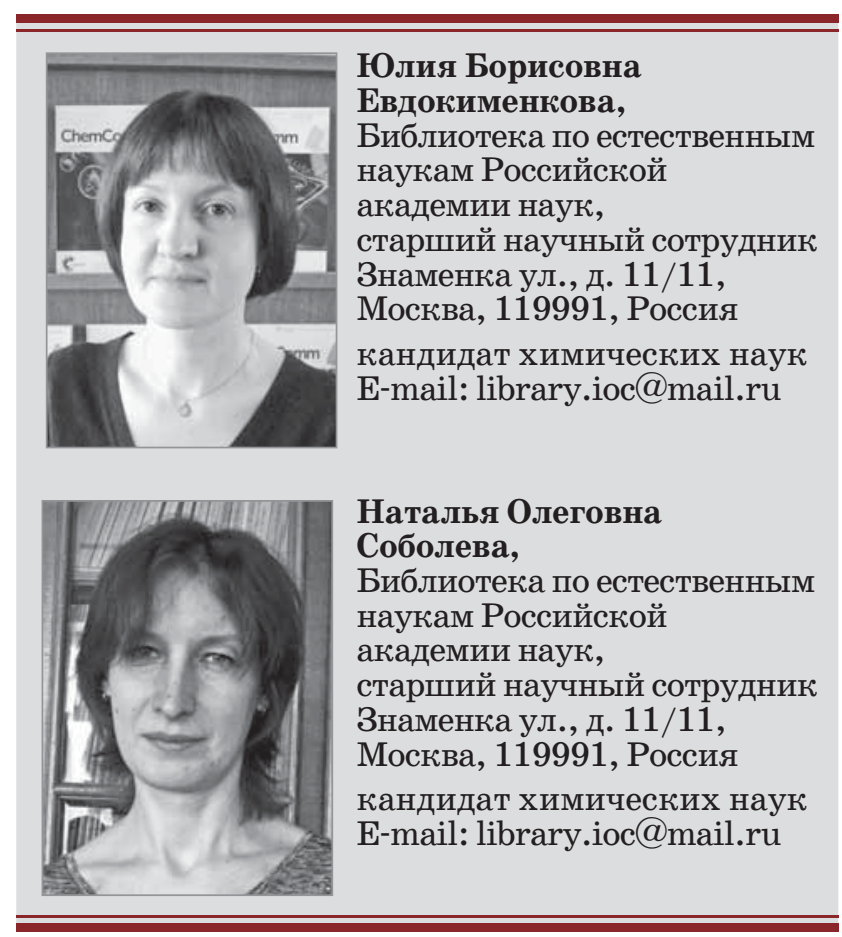


теки: университетов, вузов, научных обществ, музеев и др. Но для ежедневной работы ученых учебники, практикумы, справочники требовались непосредственно в лабораториях, поэтому многие приобретали книги в личное пользование. Также было принято дарить издания своих трудов коллегам, в том числе зарубежным, ученые получали экземпляры книг для рецензий и т. д. Некоторые специально задавались целью собрать литературу по своим профессиональным интересам, причем не только актуальную на тот момент, но и более раннего периода. Таким образом на протяжении лет складывались частные библиотеки ученых.

После смерти своих владельцев книжные собрания могли переходить в пользование наследникам, но чаще продавались ими или передавались в дар библиотекам или учреждениям, с которыми была связана деятельность ученого. Личные книжные собрания выдающихся деятелей культуры, науки, общественных деятелей - не редкость в фондах библиотек. Собрания научной литературы часто представляют не только историко-культурный интерес [1], но и сохраняют информационную значимость, поэтому вопросы, связанные с проблемой хранения и доступности таких коллекций, особенно актуальны. В одном из исследований, посвященных данной теме, «предлагается определить... личную книжную коллекцию ученого как обусловленную интересами владельца, в том числе научными, совокупность книг и других документов, подобранных в соответствии с мотивациями собирателя и имеющих научное, культурное и историческое значение» [2, с. 8].

Среди выявленных и описанных личных собраний русских ученых рубежа XIX - XX вв. библиотек, принадлежащих исследователям в области химии, не так много. Самой известной из них, пожалуй, является личная библиотека Д.И. Менделеева, хранящаяся в Музейном комплексе СанктПетербургского государственного университета (СПбГУ). Насчитывающая более 16 тыс. ед. хр., она собиралась на протяжении всей научной деятельности Д.И. Менделеева и отражает разнообразие его профессиональных, общественно-политических и эстетических интересов. По тематике книги относятся в основном к различным областям естествознания, в первую очередь химии. Существенное место в собрании занимают социально-экономические и философские труды. Многие книги и статьи были получены Д.И. Менделеевым в дар и снабжены дарственными надписями крупнейших русских и иностранных ученых: А.М. Бутлерова, Н.А. Меншуткина, И.М. Сеченова, В. Рамзая, М. Бертло, Д. Дьюара, Г. Роско, В. Оствальда и др. Художественная литература отражает все основные направления русской и зарубежной беллетристики того времени [3].

В Музее Казанской химической школы находится личная библиотека А.М. Бутлерова. Это ценное пожертвование органической лаборато- рии Казанского университета в 1890 г. сделала Н.М. Бутлерова, вдова покойного. Библиотека состоит из 364 названий в 644 переплетах. В основном представлена химическая литература: монографии, книги известных европейских и российских ученых с авторскими надписями, публичные лекции А.М. Бутлерова, лекции Н.Н. Зинина и А.М. Бутлерова, изданные литографическим способом. Здесь хранятся обе диссертации В.В. Марковникова и Е.Е. Вагнера с их автографами [4].

Личная библиотека ученых А.Е. и Б.А. Арбузовых, включающая научную, художественную, периодическую литературу, книги с дарственными надписями (всего около 3 тыс. ед. хр.), находится в Доме-музее академиков А.Е. и Б.А. Арбузовых в Казани [5].

В фондах научной библиотеки Московского педагогического государственного университета находятся книги из собрания выдающегося химика, профессора В.В. Марковникова. Эта коллекция была приобретена по рекомендации ученых-химиков Н.Д. Зелинского и А.Н. Реформатского еще в то время, когда Московские высшие женские курсы формировали свою библиотеку. В настоящее время эти издания не выделены из общего фонда отдела редких книг в обособленное коллекционное хранение и находятся в составе фонда [6]. В начале 1900-х гг. в библиотеку Московского университета поступило в дар собрание физико-химика профессора В.Ф. Лугинина.

Некоторые личные собрания ученых-химиков были переданы в дар библиотеке Высших женских (Бестужевских) курсов в Санкт-Петербурге. В 1909 г. от вдовы ученого П.П. Алексеева, профессора Киевского университета, переданы его личные книги. В 1887 г. в дар от вдовы А.М. Бутлерова была передана часть библиотеки ученого, в основном сочинения английских авторов начала XIX века. В 1899 г. в дар от вдовы М.Д. Львова, приват-доцента Технологического института, получено собрание книг, многие из которых - с автографами русских ученых. В 1900 г. от вдовы химика И.А. Тютчева, профессора Киевского университета, поступила часть библиотеки ученого. В 1905-1906 гг. наследники М.Ю. Гольдштейна, публициста, приват-доцента Петербургского университета, передали в дар издания по физике, химии, общественным наукам. В настоящее время все перечисленные коллекции находятся в фондах Научной библиотеки им. М. Горького СПбГУ [7].

В фондах библиотеки Института органической химии им. Н.Д. Зелинского (ИОХ) РАН находятся издания, принадлежавшие ранее Н.Д. Зелинскому, А.А. Титову, В.А. Кистяковскому и другим химикам, это отдельные экземпляры [8]. Некоторые выделены в коллекцию, которую составляют книги из личного собрания выдающегося русского ученого, академика Алексея Евгеньевича Чичибабина (1871-1945), первого 
лауреата Ленинской премии по химии в СССР. Жизнь его сложилась непросто. А.Е. Чичибабин родился в 1871 г. в Полтавской губернии в семье чиновника. Учился в Московском университете у профессора В.В. Марковникова. В 1892 г. А.Е. Чичибабин окончил физико-математический факультет (отделение естественных наук) Московского университета с дипломом первой степени, в 1904 г. представил к защите свою диссертацию и получил степень магистра, в 1912 г. с успехом защитил в Петербургском университете докторскую диссертацию. С 1908 г. А.Е. Чичибабин профессор Московского высшего технического училища (ныне Московский государственный технический университет им. Н.Э. Баумана). Он возглавлял кафедру органической химии, одновременно являясь деканом химического факультета [9], кроме того, в разные годы преподавал на Высших женских медицинских курсах, в Московском городском народном университете им. А.Л. Шанявского, Московском государствен-

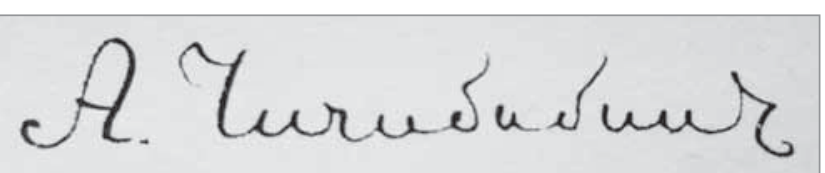

Рис. 1. Личная подпись А.Е. Чичибабина карств. Такое издание, имевшее важное значение для развития здравоохранения в стране, вышло в свет в 1925 г., главным редактором и автором всех приложений химического содержания являлся А.Е. Чичибабин, в значительной степени содействовавший его высокому научному уровню. Ученый был среди первых лауреатов премии им. В.И. Ленина в 1926 году. Так правительство отметило его работы в области химии алкалоидов и фармацевтической химии. В том же году он был избран членом-корреспондентом, а в 1928 г. действительным членом Академии наук СССР.

В 1930 г. в результате несчастного случая во время прохождения практики на Дорогомиловском химическом заводе умирает единственная дочь А.Е.Чичибабина. В этом же году, тяжело переживая такой удар, он уехал во Францию, получив отпуск от Президиума Академии наук. Там он продолжал исследовательскую и преподавательскую деятельность. За свою жизнь ученый опубликовал 346 работ (статьи в отечественных и зарубежных журналах, монографии, сборники научных трудов) [10].

В начале 1936 г. он получил письмо от непременного секретаря Академии наук СССР Н.П. Горбунова с жестким требованием вернуться на родину. Ученый ответил отказом, понимая, что его будет ждать по возвращении. В этом же году Общее собрание Академии наук СССР лишило А.Е. Чичибабина звания академика, а правительство - гражданства СССР. 22 марта 1990 г. Общее собрание Академии наук СССР приняло постановление восстановить (посмертно) в составе действительных членов Академии наук СССР Чичибабина Алексея Евгеньевича [11].

При поэкземплярном просмотре фондов отечественных и зарубежных монографий библиотеки ИОХ РАН на предмет выявления изданий до 1920 г. выяснилось, что большинство обнаруженных экземпляров имеют стертые или закрашенные надписи на титульных листах, переплетах либо их вырезанные и отреставрированные фрагменты, частично сохранившиеся дарственные надписи. На отдельных экземплярах сохранился автограф «А. Чичибабин» (рис. 1), на некоторых имелись владельческие переплеты с буквами «А.Ч.» на корешках. Мы предположили, что это книги из личного собрания академика, переданные в библиотеку после его отъезда из страны, которые попытались обезличить в связи со статусом «невозвращенца» их владельца.

Постраничный просмотр инвентарных книг показал, что при создании библиотеки в ИОХ в 1937 г. первыми в фонд были приняты две коллекции из 253 русских и 366 иностранных книг, вписанных в алфавитном порядке. Все имеющиеся на настоящее время в фонде издания, вышед- 


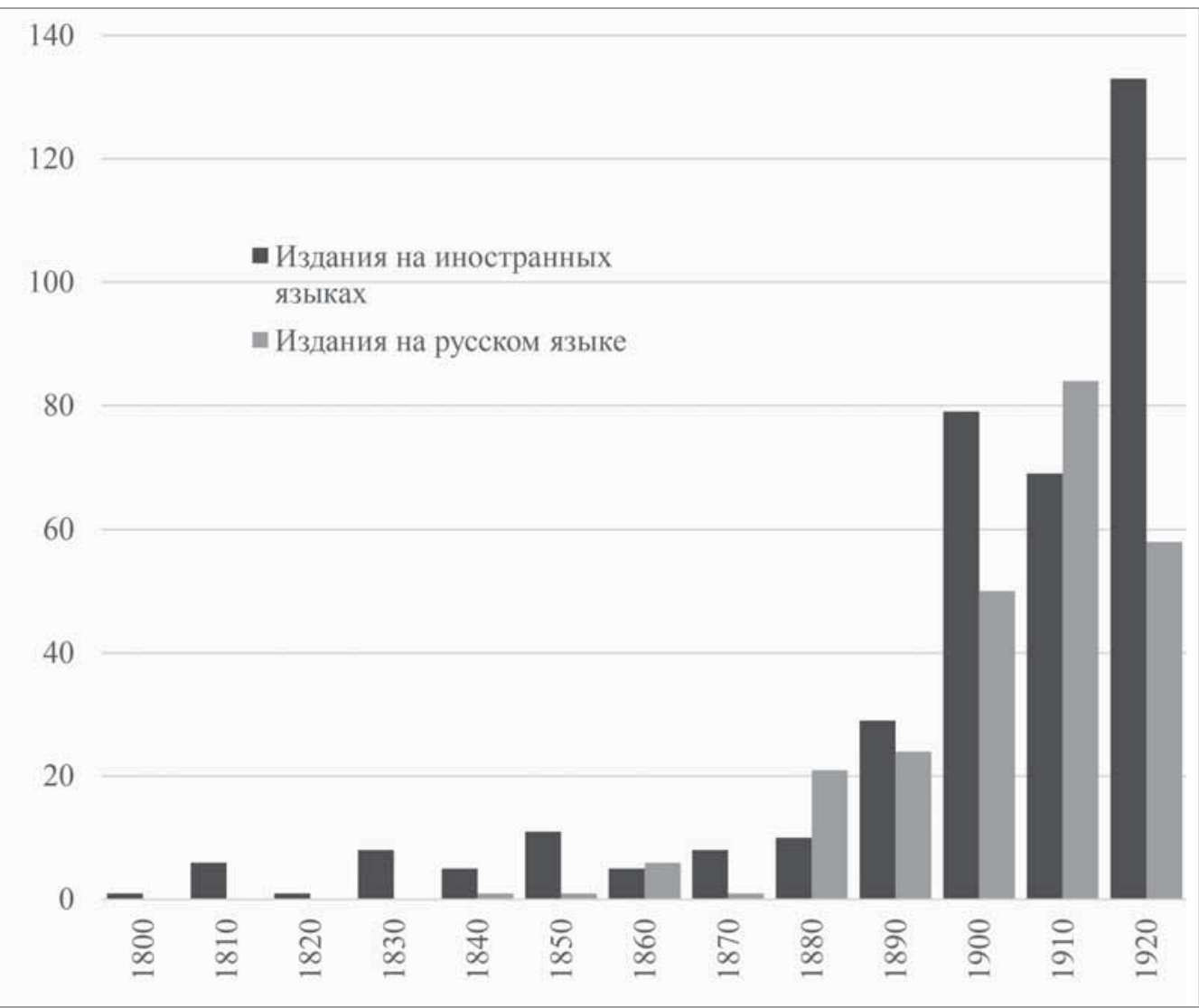

Рис. 2. Распределение отечественных и иностранных изданий по годам выпуска из коллекиии А.Е. Чичибабина развиваться, формируются научные школы в университетах Москвы, СанктПетербурга, Казани, Киева, Харькова, Риги. Преобладает литература, выпущенная в 1910-х гг., а далее ее количество снижается, что, вероятно, вызвано событиями 1917 года.

Распределение иностранной литературы по годам выпуска несколько иное, охватывается более широкий временной период, что связано с ранними этапами развития химической науки в Европе и большим распространением книгопечатания (рис. 2). Самое раннее издание - книга одного из знаменитейших врачей XVIII в., шие до 1930 г., с сохранившимися или уничтоженными владельческими знаками присутствуют в этих списках. Таким образом, можно предположить: в основу фонда монографий библиотеки ИОХ легло личное собрание книг академика A.Е. Чичибабина. В официальных публикациях об истории создания библиотеки говорится, что в ее основе - литература из фондов Химической ассоциации АН СССР [12, с. 124]. В Химическую ассоциацию, созданную в 1930 г., на правах отдельных научных организаций вошли несколько лабораторий и институтов. Среди них - Лаборатория по исследованию и синтезу растительных и животных продуктов (ЛАСИН), возглавляемая А.Е. Чичибабиным. В 1934 г. ЛАСИН вошла в состав Института органической химии [13]. Вероятно, книги академика хранились в стенах лаборатории и широко использовались в работе его учеников. После отъезда ученого они остались, а позже были переданы в библиотеку ИОХ.

Что же представляла собой эта коллекция? По имеющимся спискам был проведен анализ ее первоначального состава. Хронологическое распределение по годам выпуска отечественных изданий показало, что самое раннее из них - «Письма о химии» Ю. Либиха - относится к 1847 г., вышедших до 1890 г. - немного (рис. 2). Наибольшее число отечественных книг собрания относится к периоду 1900-1920-х гг., именно в это время русская химическая наука начинает очень быстро нидерландского ботаника и химика Г. Бургаве “Boerhaave H. Eléments de chimie” (1752). Далее мы наблюдаем закономерный рост числа изданий конца XIX - начала XX в., обусловленный научно-техническим прогрессом, и небольшое уменьшение в 1910-х гг., видимо вызванное событиями Первой мировой войны.

Языковой состав коллекции весьма разнообразен: присутствуют публикации на немецком, английском, французском, итальянском и других языках (рис. 3). Преобладают книги на немецком, в этом большую роль сыграл авторитет Немецкого химического общества - флагмана химической науки в Европе. Книги на французском языке относятся главным образом к первой половине XIX в., а издания на английском - это в основном работы американских исследователей начала XX века.

Основной тип публикаций - научные монографии, также имелись практикумы, учебники, труды университетов и институтов, словари на французском, немецком, английском и итальянском языках, важнейшие справочники по различным разделам химии, общие справочники по физике и математике. В собрание входила и периодика. В фондах библиотеки ИОХ РАН присутствуют отдельные тома немецкого "Berichte der Deutschen Chemischen Gesellschaft" и «Жћурнала Русского физико-химического общества» во владельческих переплетах с инициалами «А.Ч.» на корешках. 
По тематике среди отечественных книг преобладали издания по органической химии, общая и физическая химия представлены в меньшем объеме, существенное место занимали публикации по химической технологии, аналитической химии, фармацевтике, топливу. Все эти области науки входили в сферу непосредственных интересов академика. Кроме того, есть популярные книги по химии, истории науки и педагогике. Книги по физике были представлены многотомником «Курс физики» О.Д. Хвольсона (этот труд в значительной мере содействовал поднятию уровня преподавания физики и долгое время оставался основным пособием в советских вузах).

Наряду с работами отечественных ученых встречаются и переводные, из которых монографии Л. Мейера, Ш.А. Вюрца, Ю. Либиха, Ш. ЖЖерара являлись прижизненными переводами. Из фундаментальных трудов русских химиков в собрании имелись монографии Н.Н. Бекетова, Д.И. Менделеева, Н.А. Меншуткина, П.А. Ильенкова. Следует отметить, что наиболее капитальные из них были представлены в нескольких различных изданиях, что указывает на глубокое осмысление их содержания и важность для профессиональной деятельности.

Среди иностранных книг треть составляли работы по общей химии, остальные относились к органической, неорганической, физической химии, биохимии, химической технологии, истории науки. Имелись прижизненные издания трудов Нобелевских лауреатов по химии: Я. Вант-Гоффа, С. Аррениуса, Э. Фишера, У. Рамзая, Р. Вильштеттера, О. Валлаха, П. Сабатье, Ф. Прегля, Г. Виланда, П. Каррера, В. Оствальда; по физике: Н. Бора, Ф. Ленарда. Укажем на наличие в коллекции фундаментальных работ в области химии на более ранних этапах ее развития, в частности А. де Фуркруа, К. Фрезениуса, Л.З̊. Тенара, Ш. ЖЖерара, Т.-Жћ. Пелуза, Г. Коппа, Ф. Велера, Й.Я. Берцелиуса (причем практически все они являлись прижизненными изданиями).

На основании этого можно сделать вывод о высоком научном уровне и библиофильском характере коллекции, в которой были собраны не только актуальные на то время труды по химии, но и публикации XVIII и начала XIX в., отражавшие основные периоды развития науки.

В настоящий момент в фондах библиотеки ИОХ РАН находятся 21 экз. отечественных и 56 экз. зарубежных монографий с сохранившимися или уничтоженными владельческими метками, входившими в личное собрание А.Е. Чичибабина. Еще некоторое их число хранится в фонде Библиотеки по естественным наукам (БЕН) РАН.
Благодаря тому, что владелец подписывал свои книги в верхнем правом углу титула или форзаца полным автографом или переплетал с указанием своих инициалов, мы можем с определенной степенью достоверности утверждать, что это личные книги академика.

Некоторые издания имеют дарственные надписи. Сохранились два подписанных экземпляра, в обоих случаях дарителем являлся В.В. Шарвин, коллега ученого по Московскому высшему техническому училищу. Книга «Практическое руководство по химии красящих веществ» Р. Мелау (1927) на титуле имеет надпись: «Глубокоуважаемому Алексею Евгеньевичу А.Е. Чичибабину с сердечным приветом от редактора». На некоторых изданиях они, вероятно, присутствовали, судя по большим фрагментам, удаленным на титульных листах, или частично сохранившимся подписям «от автора». Есть и пометки другого характера, например, одно из изданий помимо подписи «А.Чичибабин» имеет владельческий штамп “C. Gustav Auerbach”, встречаются иностранные книги со штампом “Recensions Exemplar”, что говорит о существовании научных связей А.Е. Чичибабина не только в России, но и за рубежом.

Ряд изданий мы, предположительно, отнесли к личным книгам ученого, исходя из некоторых фактов его биографии, например 10 экз. фармакопей разных стран с печатью «Н.К.3. Фармакопейная комиссия Москва...», возможно, оказались в его библиотеке в период деятельности в Фармакопейной комиссии, то же самое можно сказать и о книгах со штампами «Библиотека Фармацевтического отдела Наркомздрава», отметками «Библиотека МТУ».

О том, что книги из коллекции активно использовались в работе, свидетельствует не только их наличие в стенах лаборатории, но и большое количество маргиналий, содержащихся в текстах. Это различного рода пометки, касающиеся перевода с иностранных языков, подчеркиваний со знаком «NB!», демонстрирующих важность этих фрагментов для читателя, уточнения, внесенные

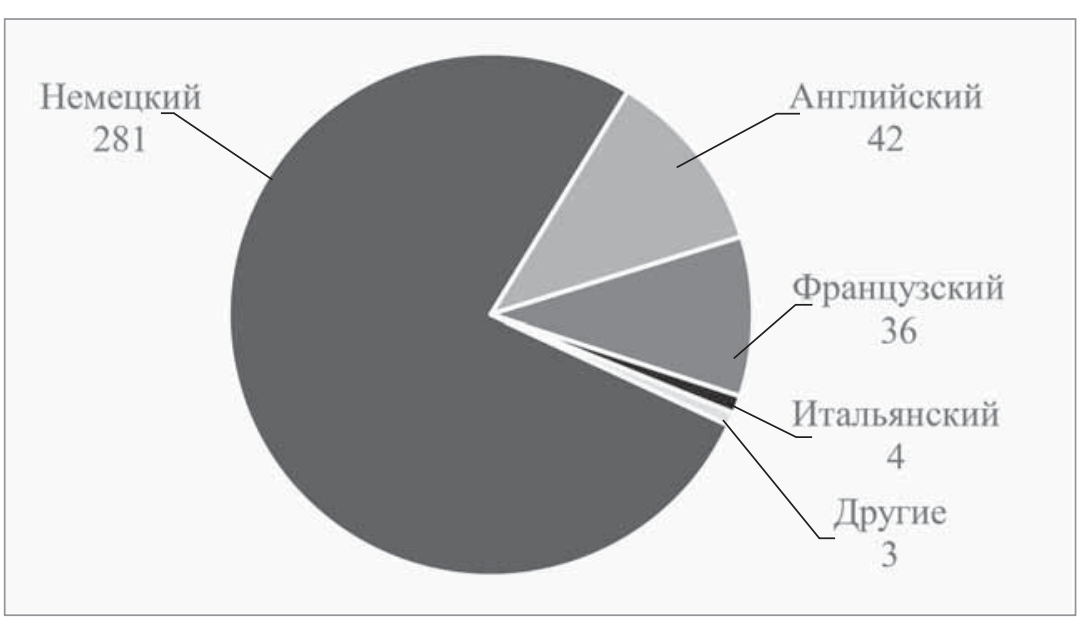

Рис. 3. Распределение иностранных изданий по языкал 
в экспериментальные данные, вероятно, полученные в результате личных опытов, и др.

A.Е. Чичибабин с большим вниманием относился к приобретению новейшей литературы необходимому условию для успешной и полноценной научной деятельности. Его личное собрание служит доказательством этому. Часть изданий имеют штампы и отметки книжных магазинов (это говорит о том, что книги приобретались на собственные средства). Косвенным подтверждением могут служить его слова из письма Н.П. Горбунову: «Даже в самые последние годы моего пребывания в СССР, когда, казалось, я был общепризнанным большим ученым, для своих работ я имел архаическую лабораторную обстановку, тогда как другие получали дворцы и много валюты для приобретения современной литературы» [14].

Таким образом, начальный этап реконструкции коллекции книг академика А.Е. Чичибабина показал, что она имела высокий научный уровень и большое информационное значение для его владельца, регулярно использовалась в исследовательской работе им лично, учениками и сотрудниками лаборатории. На целостный характер собрания указывает наличие в нем отечественных и зарубежных книг, содержащих актуальные на тот момент знания; библиофильских изданий, отражающих основные ранние этапы развития химии; справочников по различным областям химии и естественных наук; словарей иностранных языков. Сохранившиеся метки (дарственные надписи, штампы, маргиналии и др.) свидетельствуют об интенсивной исследовательской деятельности, научных связях, профессиональных интересах ученого. Имя А.Е. Чичибабина было на много лет вычеркнуто из памяти соотечественников, но его вклад в мировую химическую науку высоко ценится до сих пор [15, с. 107-108; 16$]$.

\section{Список источников}

1. Ильина О.Н. Личные библиотеки как источник по истории культуры / Вестник Санкт-Петербургского государственного университета культуры и искусств. 2003. № 1. С. 63-69.

2. Горшкова Н.Н. Личные книжные коллекции ученых в фондах научных библиотек: проблемы доступности : автореф. дис. ... канд. пед. наук. Казан. гос. университет культуры и искусств. Казань, 2012. $22 \mathrm{c.}$

3. Фонды архива Д.И. Менделеева [Электронный ресурс] / / Санкт-Петербургский государственный университет. Музейный комплекс : сайт. URL: http://muskompleks.spbu.ru/muzei-spbgu/muzejarkhiv-d-i-mendelleva/fondy-muzeya-arkhiva-d-imendeleeva.html (дата обращения: 12.04.2018).

4. Музей Казанской химической школы [Электронный ресурс] // Казанский федеральный университет.
URL: https://kpfu.ru/main_page?p_sub=14776\&p_ $\mathrm{id}=136258$ (дата обращения: 12.04.2018).

5. Дом-музей академиков А.Е. и Б.А. Арбузовых (Россия) [Электронный ресурс] // Музеи и выставки мира : каталог музеев : сайт.URL: http:// www.exmu.ru/museum_list/1956/dom_muzey_ akademikov_a_e_i_b_a_arbuzovykh/ (дата обращения: 12.04.2018).

6. Редкий фонд библиотеки МПГУ [Электронный ресурс] // Московский педагогический государственный университет. URL: http://mpgu.su/ob-mpgu/ struktura/biblioteka/iz-fonda-redkoy-knigi/ (дата обращения: 12.04.2018).

7. Список важнейших книжных коллекций, хранящихся в Научной библиотеке С.-Петербургского университета [Электронный ресурс] // Научная библиотека им. М. Горького Санкт-Петербургского государственного университета. URL: http://www. library.spbu.ru/rus/ork/chbibl.html (дата обращения: 12.04.2018).

8. Евдокиленкова Ю.Б., Соболева Н.О. Редкие книги и книги из частных собраний в фонде библиотеки Института органической химии им. Н.Д. Зелинского РАН [Электронный ресурс] // Библиотечное дело - 2016 : Библиотечно-информационные коммуникации в поликультурном пространстве : материалы 21-й Международной научной конференции (Москва, 27-28 апреля 2016 г.) / сост. и науч. ред. Л.И. Сальникова. Москва : МГИк, 2016. С. $112-117$.

9. Фадеев Г.Н., Ерлолаева В.И., Двуличанская Н.Н. Химики МГУ и МГТУ (МВТУ) : 175 лет сотрудничества // Вестник Московского университета. Сер. 2. Химия. 2005. Т. 46, № 2. С. 99-103.

10. Евтеева П.М. А.Е. Чичибабин / Т Труды Института истории естествознания и техники. Т. $18:$ История химических наук. Москва : Изд-во АН СССР, 1958. C. $296-356$.

11. Зайцева E.A. Алексей Евгеньевич Чичибабин (1871-1945) [Электронный ресурс] // Химия. 2001. № 16. URL: http://him.1september.ru/article. php?ID=200101601 (дата обращения: 12.04.2018).

12. Рубинштейн A.M. Институт органической химии имени Н.Д. Зелинского : исторический очерк. Москва : Наука, 1995. 349 с.

13. Соловьев Ю.М. Очерк великого химика // Вестник Российской академии наук. 1996. № 2. С. 165-167.

14. Волков В.А., Куликова М.В. Судьба «невозвращенца» А.Е. Чичибабина : (в свете неопубликованных документов) // Природа. 1993. № 9. С. 122-128.

15. Lewis D. Early Russian Organic Chemists and Their Legacy. Heidelberg : Springer, 2012. 136 p.

16. Lewis D. Aleksei Yevgen'evich Chichibabin (18711945) : A Century of Pyridine Chemistry // Angewandte Chemie International Edition. 2017. № 33. P. 9660-9668.

Иллюстративный материал предоставлен авторали статьи 


\title{
The Materials for Reconstruction of the Private Library of Academician A.E. Chichibabin
}

\author{
Yulia B. Evdokimenkova, Natalya O. Soboleva, \\ Library for Natural Sciences of the Russian Academy of Sciences, 11/11 Znamenka Str., Moscow, 119991, \\ Russia \\ E-mail: library.ioc@mail.ru
}

\begin{abstract}
Abstact. Libraries of Russian scientific institutions keep private book collections of the outstanding scientists. They are valuable objects of cultural and historical research, while maintaining some of their informational importance. The article describes the collection of A.E. Chichibabin, the famous chemist and academician. It was discovered in the library of the N.D. Zelinsky Institute of Organic Chemistry of the Russian Academy of Science. The collection was given to the library after the scientist's departure from the country and was depersonalized because the owner had been deprived of his academic ranks and USSR citizenship. The initial stage of the collection's reconstruction has been carried out using the survived copies with the owner's marks and the lists of received books. All identified publications have a personal signature of the scientist or traces of its earlier presence; a number of copies contain endowment inscriptions, proprietary notes and bookstore marks. The qualitative analysis shows that the publications' subject matter refers to various areas of chemical science, representing the owner's direct professional interest. The collection is fairly wide in chronological coverage, diverse in type of publications (monographs, periodicals and reference publications, university proceedings, dictionaries, practical manuals, etc.) and multilingual. Its high scientific level is evidenced by the presence of works of many outstanding Russian and foreign chemists, Nobel laureates of the early 20th century. The bibliophilic nature of the collection is emphasized by the presence of books of the 18th and early 19th centuries, reflecting the main periods of science development. Further study of the publications from the personal library of academician A.E. Chichibabin will add new touches to the scientist's biography, the history of formation of his scientific school and help to trace his scientific and personal ties with colleagues from Russia and other countries.
\end{abstract}

Key words: Private Library, Scientific Heritage, History of Chemistry, A.E. Chichibabin.

Citation: Evdokimenkova Yu.B., Soboleva N.O. The Materials for Reconstruction of the Private Library of Academician A.E. Chichibabin, Bibliotekovedenie [Library and Information Science (Russia)], 2018, vol. 67, no. 3, pp. 291-298. DOI: 10.25281/0869-608X-2018-67-3-291-298.

\section{References}

1. Ilyina O.N. Personal Libraries as a Source on the History of Culture, Vestnik Sankt-Peterburgskogo gosudarstvennogo universiteta kul'tury i iskusstv [Bulletin of the St. Petersburg State University of Culture and Arts], 2003, no. 1, pp. 63-69 (in Russ.).

2. Gorshkova N.N. Lichnye knizhnye kollektsii uchenykh $v$ fondakh nauchnykh bibliotek: problemy dostupnosti [Personal Book Collections of Scientists in Scientific Libraries: Accessibility Problems], Cand. ped. sci. diss. abstr. Kazan, 2012, 22 p.

3. D.I. Mendeleev's Archives, Sankt-Peterburgskii gosudarstvennyi universitet. Muzeinyi kompleks [St. Petersburg State University. The Museum Complex]. Available at: http://muskompleks.spbu.ru/muzeispbgu/muzej-arkhiv-d-i-mendelleva/fondy-muzeyaarkhiva-d-i-mendeleeva.html (accessed 12.04.2018) (in Russ.).

4. Museum of the Kazan School of Chemistry, Kazanskii federal'nyi universitet [Kazan Federal Univer- sity]. Available at: https://kpfu.ru/main_page?p_ sub=14776\&p_id=136258 (accessed 12.04.2018) (in Russ.).

5. The Memorial Museum of Academicians Alexander and Boris Arbuzovs, Muzei i vystavki mira : katalog muzeev : sait [Museums and exhibitions of the world: a catalog of museums]. Available at: http:// www.exmu.ru/museum_list/1956/dom_muzey_ akademikov_a_e_i_b_a_arbuzovykh/ (accessed 12.04.2018) (in Russ.).

6. Rare Collections of the Library of the Moscow Pedagogical State University, Moskovskii pedagogicheskii gosudarstvennyi universitet [Moscow Pedagogical State University]. Available at: http://mpgu.su/obmpgu/struktura/biblioteka/iz-fonda-redkoy-knigi/ (accessed 12.04.2018) (in Russ.).

7. A List of the Most Important Book Collections Stored in the Scientific Library of the St. Petersburg University, Nauchnaya biblioteka im. M. Gor'kogo 
Sankt-Peterburgskogo gosudarstvennogo universiteta [M. Gorky Scientific Library of the St. Petersburg State University]. Available at: http://www.library. spbu.ru/rus/ork/chbibl.html (accessed 12.04.2018) (in Russ.).

8. Evdokimenkova Yu.B., Soboleva N.O. Rare Books and Books from Private Collections in the Library of the N.D. Zelinsky Institute of Organic Chemistry of the Russian Academy of Sciences, Bibliotechnoe delo - 2016: Bibliotechno-informatsionnye kommunikatsii $v$ polikul'turnom prostranstve: materialy 21-i Mezhdunarodnoi nauchnoi konferentsii (Moskva, 27-28 aprelya 2016 g.) [Proceedings of the 21 st International Scientific Conference "Librarianship - 2016: Library and Information Communications in the Multicultural Space" (Moscow, April 27-28, 2016)]. Moscow, MGIK Publ., 2016, pp. 112-117 (in Russ.).

9. Fadeev G.N., Ermolaeva V.I., Dvulichanskaya N.N. Chemists of the Moscow State University and Bauman Moscow State Technical University: 175 Years of Cooperation, Vestnik Moskovskogo universiteta. Ser. 2. Khimiya [Moscow University Chemistry Bulletin], 2005, vol. 46, no. 2, pp. 99-103 (in Russ.).

10. Evteeva P.M. A.E. Chichibabin, Trudy Instituta istorii estestvoznaniya i tekhniki. T. 18: Istoriya khimiches- kikh nauk [Proceedings of the Institute for the History of Science and Technology. Vol. 18: The History of Chemical Sciences]. Moscow, AN SSSR Publ., 1958, pp. 296-356 (in Russ.).

11. Zaitseva E.A. Aleksei Evgenyevich Chichibabin (1871-1945), Khimiya [Chemistry], 2001, no. 16. Available at: http://him.1september.ru/article. php?ID=200101601 (accessed 12.04.2018) (in Russ.).

12. Rubinshtein A.M. Institut organicheskoi khimii imeni N.D. Zelinskogo: istoricheskii ocherk [N.D. Zelinsky Institute of Organic Chemistry: Historical Essay]. Moscow, Nauka Publ., 1995, 349 p.

13. Solovyov Yu.M. An Essay of the Great Chemist, Vestnik RAN [Herald of the Russian Academy of Sciences], 1996, no. 2, pp. 165-167 (in Russ.).

14. Volkov V.A., Kulikova M.V. The Fate of the "NonReturnee" A.E. Chichibabin (In the Light of Unpublished Documents), Priroda [Nature], 1993, no. 9, pp. 122-128 (in Russ.).

15. Lewis D. Early Russian Organic Chemists and Their Legacy. Heidelberg, Springer Publ., 2012, 136 p.

16. Lewis D. Aleksei Yevgen'evich Chichibabin (18711945): A Century of Pyridine Chemistry, Angewandte Chemie International Edition, 2017, no. 33, pp. 96609668.

\section{Анонс}

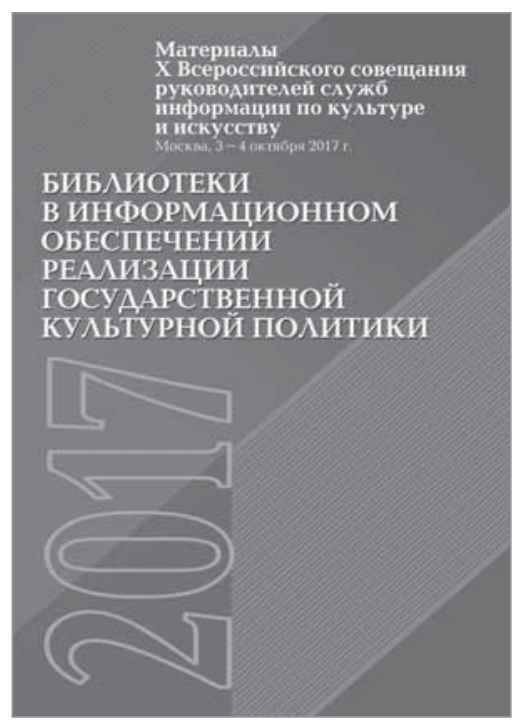

Библиотеки в информационном обеспечении реализации государственной культурной политики : материалы X Всероссийского совещания руководителей служб информации по культуре и искусству : Москва, 3-4 октября 2017 г. / Российская гос. б-ка ; [сост. А.В. Горбунова ; отв. за вып. И.П. Тикунова]. Москва : Пашков дом, 2018. 218 с.

Сборник содержит материалы X Всероссийского совещания руководителей службб информации по культуре и искусству «Библиотеки в информационном обеспечении реализации государственной культурной политики» (3-4 октября 2017 г.), организованного Российской государственной библиотекой в партнерстве с Санкт-Петербургским государственным институтом культуры.

Опубликованы доклады и сообщения участников, итоговый документ, новая редакция «Положения о Российской системе научно-информационного обеспечения сферы культуры», «Положение о VI Всероссийском смотре-конкурсе библиотек на лучшее электронное издание по культуре и искусству» и информация о победителях и лауреатах этого конкурса, подведение итогов которого состоялось на совещании.

Справки и заказ изданий:

119019, Москва, ул. Воздвиженка, $3 / 5$

Российская государственная библиотека, Отдел книжных изданий +7 (499) 557-04-70, доб. 25-72; Pashkov_Dom.Book@rsl.ru http://store.rsl.ru/service/pashk̄ov_dom 